\title{
Methods for studying innovation processes: Towards a complementarity between organizational and cognitive perspectives
}

\author{
VALÉRIE CHANAL ${ }^{1}$
}

\begin{abstract}
This paper describes two methods designed to study and diagnose innovation processes. The first one adopts a systems perspective and focuses on information flows and decision-making during a project, whereas the second one privileges a cognitive approach and is aimed at highlighting actors' representations of innovation processes and new products. A comparison of the research results obtained in different industrial firms using these two methods introduces a discussion of the complementarity of both perspectives. These observations lead to an assessment of the collective learning mechanisms initiated during the field studies.
\end{abstract}

\section{Introduction}

In the broad and varied field of research on innovation, researchers have focused on different levels of analysis to study this complex phenomenon. At the social and economic level, the innovation process has traditionally been considered as a black-box and research studies have considered either the inputs (such as technological change, $R \& D$ expenditure or users' needs) or the outcomes (success or failure of the new product on the market). The inherent limit of these approaches is that they assume that only inputs or outcomes can be explained in sociological or economic terms (Flichy, 1995). Management researchers (e.g. Van de Ven and Poole, 1990) as well as economists (e.g. Ménard, 1994) and sociologists (e.g. Flichy, 1995) now claim that it is urgent to shift research on innovation towards the intra-organizational level and to consider technological and organizational innovation as mutually dependent. Again, this new concern on intra-organizational processes has been addressed with different perspectives. On the one hand, the evolutionist theory considers innovation as an incremental learning process and

\footnotetext{
${ }^{1}$ Université de Savoie, BP 1104, 73011 Chambéry Cedex, France. E-mail: Valerie.Chanal@univ-savoie.fr Keywords: Innovation management, methodology, system theory, cognitive representations, organizational learning.
} 
establishes a link between a technological invention and the generation of new knowledge within the firm (Nelson and Winter, 1982). Researchers in this tradition see organizational learning as a process in which organizations adapt to changing environments by generating and selectively adopting organizational routines (Argyris and Schön, 1996). On the other hand, cognitive oriented approaches mainly focus on social interactions at the team level and consider the design process as a creation of collective representations of a technical artifact (Garel and Midler, 1995; Hatchuel, 1994).

This paper is based on the assumption that both levels - organizational and cognitive should be integrated in a study of the innovation process. Turning an innovative idea into an economic reality actually requires the existence or the emergence of an adequate organizational structure (Ménard, 1994). The firm's capability of "absorbing" innovations depends on organizational knowledge management (Cohen and Levinthal, 1990). It is linked to different factors such as the absorptive capacity of "gatekeepers", the sort of knowledge that individuals possess, the level of diversity and redundancy of knowledge, and knowledge transfer efficiency within the firm (Cohen and Levinthal, 1990). Furthermore, a description of the temporal sequence of activities is not sufficient to improve our understanding of internal mechanisms which explain innovation success. It is also necessary to study human interactions throughout the project, inside or outside the organization (Van de Ven and Poole, 1990; Flichy, 1995).

One of the most important issues of this growing interest in process research on innovation is, in our opinion, a methodological one. Indeed, all the ingredients of complexity are present:

- the difficulty to apprehend the time variable (when innovation processes actually start and when they finish);

- the co-existence of different rationales and individual strategies;

- the dilemma between the importance of experience based on a memory that fosters collective learning and the necessity to break away from organizational routines;

- the role of tacit knowledge;

- the specificity of each innovation project making it difficult to apply generic rules.

Consequently, research studies have attempted to better understand the social, technical and economic mechanisms likely to lead to success or failure. Many of these are based on longitudinal field research methods widely acknowledged as relevant for the understanding of organizational change (Pettigrew, 1990, 1992; Van de Ven and Huber, 1990; Van de Ven and Poole, 1990). The Minnesota Innovation Research Program (Van de Ven and Poole, 1990) or the study of the Twingo development project by Renault (Midler, 1996) are typical examples of such longitudinal research methods.

This article presents two different methods for studying innovation processes. Their aim is to provide innovation managers with tools or heuristics that can help them to design more innovative structures and to identify successful paths in the management of innovation. These two methods enable the identification and evolution of the actors' cognitive representations in order to generate organizational learning.

Part I introduces the conceptual framework of this research referring to the concept of "knowledge-based organizations". Its central assumption is that innovation is mainly a process of transfer and creation of organizational knowledge enabling a connection between market needs and the firm's technological competencies. We will examine 
the two main theoretical interpretations of knowledge-based organizations. The first approach considers organizations as information-processing systems and focuses on organizational co-ordination and decision-making. The second one underlines the emergence of new meanings and knowledge through social interactions (Weick, 1995; Nonaka, 1994). It considers organizations mainly as interpretation systems (Daft and Weick, 1984). These two theoretical perspectives have guided the design and implementation of two methods of diagnosis presented in Part 2. In the following part, three case studies carried out in different industrial contexts illustrate the kind of results obtained by using these methods. Our observations lead to an assessment of the collective learning mechanisms initiated during these field studies. The discussion stage will consider how the interplay between the organizational and the cognitive levels could enrich the diagnosis of the firms' innovation capability.

\section{Innovation: a process of knowledge management}

\subsection{Knowledge-based organizations (KBO)}

For most researchers and managers, knowledge has become a major source of competitive advantage, if not the only one (Roos and Von Krogh, 1996; Baumard, 1996). Research studies referring to the KBO framework are based on the assumption that knowledge, and more specifically tacit knowledge, is the most important strategic resource of the firm (Nonaka, 1994; Roos and Von Krogh, 1996; Baumard, 1996; Grant, 1996; Tsoukas, 1996). Only the appropriate management of this knowledge will enable a strategic differentiation through innovative behavior, since current management activities are now almost fully standardized and cannot provide a durable source of differentiation (Von Krogh et al., 1994). The KBO approach is broadly divided into two main theoretical streams that we will qualify as the systems (or information-processing) approach and the cognitive approach, although both perspectives are made up of many different variants ${ }^{1}$, which it is not possible to present in this article.

\subsection{Innovation: an information-processing system}

The most common definition of KBO considers organizations as information processing systems (IPS) (Newell and Simon, 1972; Le Moigne, 1990). As Le Moigne (1990) argues, the organization seen as an IPS is a complex, autonomous and intelligent system, capable of designing its own projects, and adapting its behavior and organization to its own objectives. The traditional sequential descriptions of innovation processes are often considered as an oversimplification of the innovation phenomenon, whereas the modeling of complex systems (Le Moigne, 1990) aims to provide a global understanding of

\footnotetext{
${ }^{1}$ We include in the cognitive approach the following research streams: Situated Action (Suchman, 1987), Enaction (Varela, 1989), Autopoïesis (Maturana and Varela, 1994), Distributed Cognition (Hutchins, 1995). By contrast the information-processing view (Newell and Simon, 1972) is often referred to as: the systems, paradigmatic, cognitivist, or symbolic-processing perspective of organizational cognition.
} 
these systems. This systems modeling approach applied to innovation processes consists in analyzing the following three levels:

- the operating system (OS) considers concrete activities that are undertaken over time (such as the development of a prototype);

- the information system (IS) includes information gathering, memorizing and communicating (such as transmitting results from a user-study);

- the decision system (DS) covers decision-making, decision co-ordination and the definition of objectives (such as deciding to fund a development project).

The systems approach can be considered as a significant improvement on the analytical models of the innovation process limited to a representation of a sequence of activities. It leads to a better understanding of key decision-making steps by focusing on information flows between phases (Brown and Karagozoglu, 1989). New practices of project management such as concurrent engineering are applying a systems perspective with several activities being undertaken simultaneously and a focus on lateral co-ordination to optimize design and development delays. Similarly, decisions requiring significant resources tend to be taken as late as possible to avoid closing up possible alternatives prematurely.

\subsection{Innovation: a knowledge-creating process}

Some authors are not satisfied with the information-processing paradigm for studying innovation. Nonaka (1990) considers that this paradigm is inadequate to understand the complexity of innovation, defined as "the organizational phenomenon of the creation of new order through the acting upon of redundancy and chaos". Innovation is actually difficult to model and to observe as it involves improving existing solutions and simultaneously looking for new ones (March, 1991). Therefore, innovation can be considered as an on-going learning process (Paulré, 1993). Flichy (1995) also recommends rethinking traditional theories of innovation and argues that any new product design is a collective enactment of the product's usage and its technical features. These alternative views refer to a cognitive or interactionnist framework to understand organizational cognition. This theoretical perspective, put forward by Weick $(1979$; 1995) or Varela $(1989)$, considers individual or collective cognition as a process of knowledge creation rather than symbolic processing. In this regard, organizational knowledge emerges through the day-to-day social interactions and is supported by language (Von Krogh et al., 1994). The implementation of a cognitive-oriented research method would thus involve the analysis of collective representations and meanings assigned to knowledge and to actions during a project.

\subsection{Implications for the study of innovation processes}

Systems and cognitive approaches of knowledge-based organizations may address objections that are often raised about research studies using analytical approaches. Research results are often considered as being reported on a variable-by-variable basis whereas managers tend to think in terms of general schemes or scenarios (Cooper, 1983; Van de Ven, 1986). Furthermore, actors and social interactions are not really taken into account within traditional models. 
The main assumptions derived from these two theoretical views of organizational knowledge can be summarized as follows:

1) Improving the innovative capability of an organization within a systems perspective requires:

- the availability of information (outside the firm or within the organizational memory);

- the rapid processing and diffusion of information so that decision-makers can formulate their objectives and take satisfying decisions.

2) Improving the innovative capability of an organization within a cognitive perspective requires:

- spaces or tools enabling social interactions, so that people can exchange expertise, approach problems in a different way, imagine new solutions, and create new organizational knowledge;

- the creation of a shared interpretation frame about key issues of a project based on a common language.

\section{Diagnosis of innovation processes}

\subsection{The objective: collective learning and organizational change}

The aim of the diagnosis methods presented hereafter is to initiate an iterative process of co-construction of new meanings by the researcher and the managers. The purpose is to produce "actionable" knowledge, to use the expression of Argyris (1995). This type of diagnosis requires that the researchers devote enough time to the field study to allow for a modification of interpretation frames. This change in collective representations constitutes a point of leverage for organizational learning. Whereas the processing of information based on experience or on the imitation of other firms can affect the way people react in specific situations (the "single-loop learning" of Argyris and Schön, 1978), an evolution of interpretation frames may lead to a deeper change of organizational rules, and therefore to innovative behavior ("double-loop learning"). What is at stake is the way in which managers view the ongoing innovation process (time, roles, information) and how they imagine the product itself (applications, functions, market targets, technical aspects). The reification of practices and implicit representations facilitates a collective negotiation of meaning and thus generates a learning process (Wenger, 1998).

\subsection{A systems-oriented method for diagnosing innovation capability}

The method used for this research was based on a software diagnosis tool (a knowledgebased system $)^{2}$. The knowledge-base which constitutes the reference system of the

\footnotetext{
${ }^{2}$ For a detailed presentation of this method, the reader can refer to our doctoral dissertation (Chanal, 1995).
} 
diagnosis relied on a comprehensive synthesis of the literature on innovation management, from 1970 to 1994.

A base of 150 rules, drawn from this theoretical corpus was formalized as illustrated in the example below (Tab. 1).

TABLE 1. - Examples of rules drawn from a literature analysis to build the theoretical reference base of the diagnosis system.

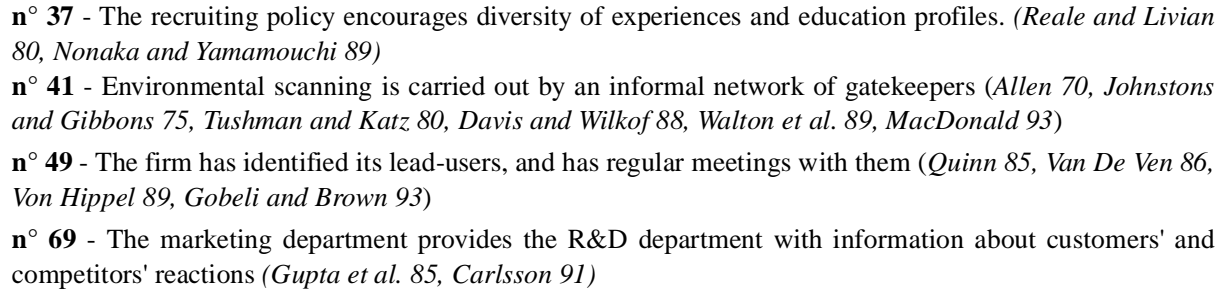

The user does not, of course, have access to these rules as such. They are organized in the system within a $2 \times 2$ matrix: the first dimension concerns the temporal phase of the analyzed project and the second focuses on the main elements of the information processing system: information access, memorization of information, internal coordination, decision-making. The rules are also weighted according to their expected impact on the overall success of the project. The computer-based system is used to pilot interviews with members involved in an innovation project. It then displays a synthetic chart with main strengths and weaknesses for each phase of the project. The user can then ask for complementary explanations or suggestions by clicking on one cell of the chart (Tab. 2).

This diagnosis system was implemented in three medium-size industrial firms manufacturing electronic products. After holding individual interviews with all project members, we organized a final meeting during which main issues and perception differences were discussed with all the participants. The main interest of this diagnosis tool has proved to be the immediate, structured and argumentative feedback of the innovation process. This reification of both theory on innovation management and individual representations is the basis for a collective discussion on the way a project team manages the innovation process and may lead to the creation of new interpretation frames, as we will see in part 3 .

\subsection{A cognitive-oriented method for diagnosing innovation capability}

Many researchers now use cognitive mapping in organization studies, to highlight individual or collective representations (Cossette and Audet, 1994). Cognitive maps are graphical representations of a perceived situation drawn up by the researcher on the basis of information obtained during interviews. These maps represent the main concepts and the causal links between issues. A less frequently used method was adopted for this research. It is based on the lexical analysis of language. The main reason for choosing this parti- 
TABLE 2. - An example of display of diagnosis for one phase of the process.

\begin{tabular}{|l|l|l|l|}
\hline Phase of idea generation & OK & Must progress & Priority efforts \\
\hline Organization & & & \\
\hline Rules, values, leadership & & & \\
\hline Organizational structure & & & \\
\hline Human resources management & & & \\
\hline Information system & & & \\
\hline Business intelligence & & & \\
\hline Marketing information & & & \\
\hline Technological information & & & \\
\hline Storage of information & & & \\
\hline Decision -making & & & \\
\hline Objectives setting & & & \\
\hline Creativity, idea generation & & & \\
\hline Internal communication & & & \\
\hline
\end{tabular}

If the user clicks on the cell "marketing information", in the column "priority efforts", the system can display the following type of comment:

The sales-force seems not to be aware of the necessity to collect information about future user-needs. You could start by organizing meetings to discuss the strategic importance of collecting qualitative marketing information and to see how this could be done concretely. This type of mission could also be included as a qualitative objective within their annual objective setting.

cular method is that organizational language is considered to be extremely important when a firm is about to develop a new product. As Roos and Von Krogh (1996) claim, the successful launch of a new product is directly linked to the firm's ability to create and spread a new language at all operational levels. Furthermore, language does not only have a communication function but also a cognitive function (Girin, 1990). However, it is paradoxical to note that few studies have been dedicated to organizational language (Roos and Von Krogh, 1996; Girin, 1990). As far as the management of innovation projects is concerned, we identified only one research study using language analysis to understand the dynamics of a project in time (Fiol, 1994). In the two cases described below, we have analyzed interviews and written documents on innovation projects, with a lexical analysis software (Sphinx Lexica $\left.{ }^{\odot}\right)$.This type of processing consists in a statistical analysis of words occurrence. It is thus possible to identify almost instantaneously the most frequently discussed issues and to analyze specificity of language and areas of common language. In addition, the analysis of the lexical environment of keywords gives an indication of the meaning that individuals place on these words.

This method was implemented in two French firms manufacturing products for the building industry. In the first enterprise, one of the main issues was to improve the management of innovation projects and to set up a project-oriented organization. The main 
contribution of this action - research was to design an internal document explaining the innovation policy, the new organization, and various rules to manage innovation projects. Ten managers participating in the formulation and implementation of the innovation policy were interviewed. The interviews were analyzed using the lexical analysis software. All the participants involved were then invited to exchange their views and comment on the results of the study in a final meeting.

The second research was designed as a case study. The objective was to identity the factors which had led to the termination of a project involving three partners: a private industrial firm, a public enterprise, and a design consultant. We met with different managers in each of these three organizations and asked them about the story of the project and their interpretation of the decision to stop it.

We now turn to the description of some research results obtained with the two methods presented above. These results are only given as an illustration of the methods and should not be considered as the central purpose of this paper.

\section{Research results}

\subsection{Case study $n^{\circ} 1:$ the issue of market-orientation}

Our observations on the issue of market orientation illustrate the advantages of a systems perspective. Studies of key factors leading to new product success generally conclude with the importance of a market orientation, but they rarely offer concrete measures to improve the understanding of users' needs.

Our field observations led to a more detailed diagnosis of the main difficulties involved in collecting, processing, storing and distributing market information within the firm. In the three firms under study, two main sources of marketing information were identified: the sales-force and distributors, and the so-called "lead-users" (Von Hippel, 1989) representing the more innovative clients. An in-depth analysis of information flows showed that these firms faced two main problems:

- the motivation of the sales-force to collect and communicate information about customer needs;

- the interpretation of this information to provide new ideas for the development of new products.

The market-orientation issue which is generally addressed globally by researchers in fact covers different levels of problems. In certain firms, salespeople do not sufficiently collect or communicate market information. In this case, measures can be taken in order to recruit and train the sales team to cope with the evolution of many industrial sectors: product customization, customer awareness, long-term client-supplier relationships, development of service and quality (Glazer, 1991). In other firms, the main problem is not the competence of the sales team but the ability of the marketing department to process customer information. The following quotes illustrate this point:

"If we ask sales people to include market information in their sales report, the marketing department is likely to be overloaded with information!" 
"Customers claims are reported, even too often! But they come in one after the other and are never synthesized."

This type of problem calls for other solutions such as the creation of discussion groups involving the sales and marketing departments or the use of information technologies to store and process all information concerning markets and customer requirements. The problem of market orientation, often described as the most important issue in the management of innovation, can thus be modeled in order to identify the main difficulties in the market information process (Fig. 1).

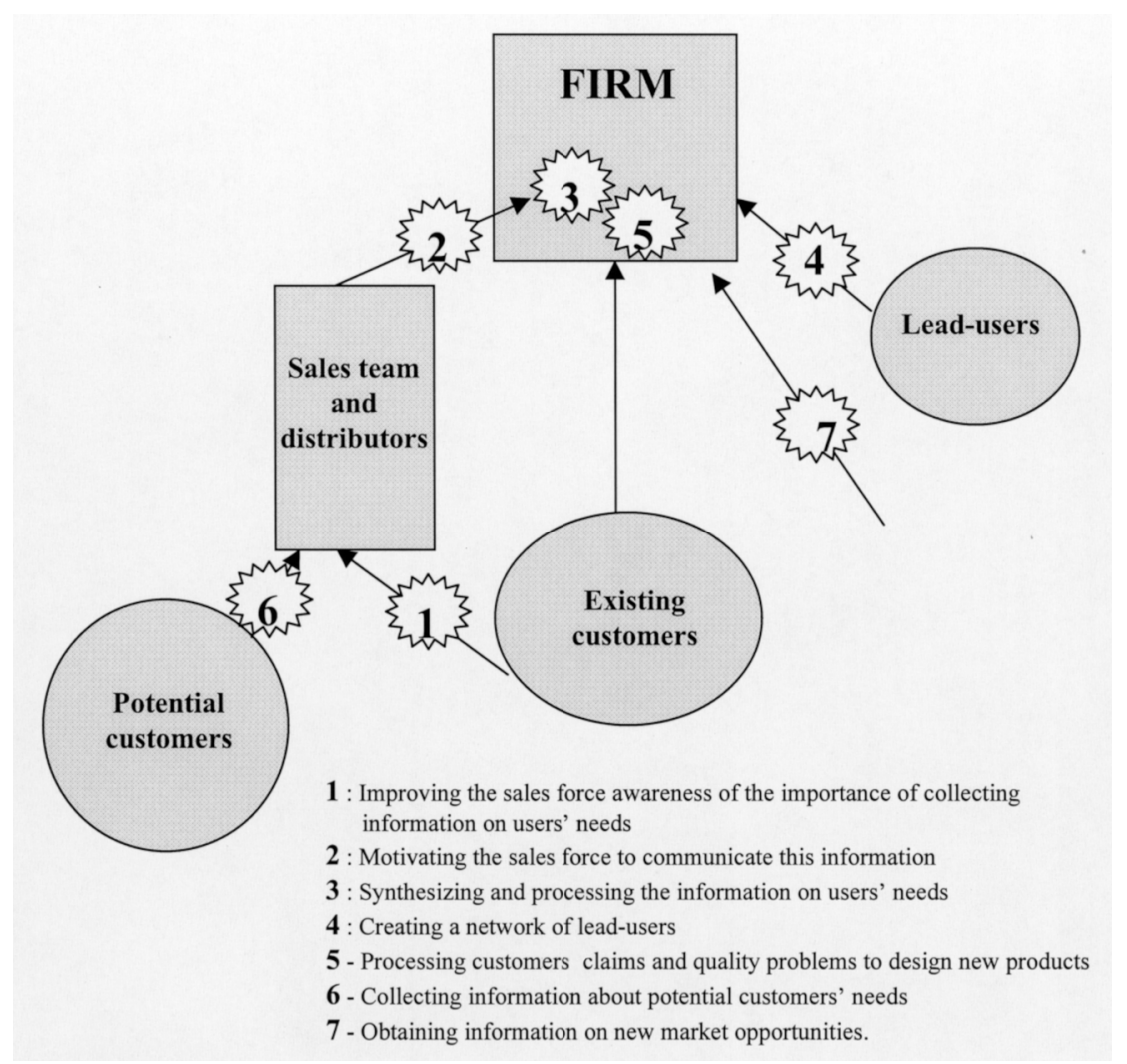

Fig. 1. An example of systems diagnosis: identification of key points in the processing of market information.

Another type of observation illustrates how collective representations evolve and thus form a basis for a learning process. One of the firms was a market leader and the interviews revealed a lack of concern with the competition. The following comments were made during the individual interviews, at the beginning of the study:

"Your questions might be more adapted to firms where competitive pressure is high. The market growth in our sector is very significant and firms can hardly meet the demand."(Managing Director) 
"Competition within our sector is quite low. The marketing methods that are suggested here would be more relevant if competition were more intense." (Project Manager)

"I can't see the point of checking up on our competitors. We are the leaders. The others are imitating us." (Technical Manager)

These remarks show that the diagnosis tool, and the underlying theoretical reference frame, is challenged by the managers. They believe that it is not adapted to their competitive situation. However, we did observe a change in their appraisal of competition threats during the final meeting, as shown by the following dialog:

Researcher: We have noted a weakness in the information system of the competition. This may be due to the fact that the competitive intensity is not very high and that your firm is a market leader.

Managing director: No, that's not true. Competitive pressure is high. We have very innovative competitors. Their innovation concerns markets more than it does technologies. Some customers are also likely to become competitors. We must be more aware of the competition.

Researcher: Your information files on competition are mainly product oriented and do not include strategic information.

Research Manager: Yes, you're right. We have indirect competitors and new entrants, such as customers who are integrating our business. We have no information on their strategy. We have already been surprised.

This new perception of the competition can be viewed as an evolution of interpretation frames. Competition is no longer considered merely as a technological issue but now integrates market factors and potential entrants such as customers. This evolution can, in our opinion, provide a basis for a collective learning process. What has changed is both the observation field and the interpretation frame of a specific situation: a customer's action can henceforth be interpreted as a strategic threat. These change levels are comparable to those defined by Bateson (1977) in his presentation of the different learning levels (levels 2 and 3).

\subsection{Case study $n^{\circ}$ 2: a diagnosis of organizational language}

This action research in a firm of the building sector was carried out with the purpose of designing a project-oriented organization. The study of the language of the project team members enabled the identification of significant language differences that could hinder collective action. The word "marketing" for instance was one of the 24 nouns common to all ten managers interviewed. Although this word belongs to the common business vocabulary, one interviewee used it extensively (62 times out of a total of 135 occurrences) whereas others referred to it only once or twice. In our lexical analysis, this word had the highest specificity index of all the common vocabulary. 
A study of the lexical environment of "marketing" shows that this term is often qualified by exclusive adjectives (i.e. pronounced by only one person), such as "transversal", "functional", "operational", "technical". The specific use of the concept of marketing in this firm can nourish the assumption that project members do not share the same vision of what the marketing mission should be. This is confirmed by the vague understanding of the marketing function, especially among technical people:

"Marketing, it's packaging, technical documentation, they deal with all this kind of stuff it's important."

"I don't do any marketing, or what I do is re-read technical files"

"He also has a marketing job, press relations and things like that."

On the basis of this language analysis we drafted an internal communication brochure outlining the management procedures for new product development. A previous version drawn up by the management had used, for instance, the word "system" to promote the idea of offering global services to the customer. Our observations however brought to light the negative connotations of this term ("a heavy system", "to block the system", "you bury yourself in the system") and led us to caution the management against the use of this word. The final discussion with all the participants also revealed that such concepts as value and value chain were not clearly understood. Consequently we agreed that the document should explain and exemplify the concept of value.

Lastly, this study identified the crucial lack of a common strategy framework. Not only were the words "strategy" and "strategic" used very little (only 11 times in the ten interviews, and 6 times by one marketing manager), but significant gaps in the perception of the strategic importance of innovation for the firm were also identified, as illustrated by the following comments:

"My view is that not being innovative is not the main problem. What I'd really like first, is for us to have real quality procedures. I'm convinced that we can be successful by being the follower rather than the leader. " (Department Manager)

"We've got to innovate. We've got to bring out one or two new products every year. And we mustn't imitate the competition, we really have to be an innovator, a leader." (Marketing Manager)

"If we don't develop new products, we disappear, if we don't improve the quality of our product line, we disappear. We have to succeed in both areas." (Product Development Manager)

To sum up, this study allowed a team of managers to become aware that certain aspects of the organization's language can cause communication difficulties and hinder innovation management. In this firm, new measures were taken on the basis of this study such as the design of an internal document understandable by all emphasizing the strategic importance of innovation and the introduction of training programs in marketing.

Collective learning was based in this case on an objectification of the language used. Actors were most surprised to see their relative position on a "language map" and realized that communication within a project team could be impacted by vocabulary ambiguities. The internal document helped to clarify the roles of the marketing managers and of the project managers in the innovation projects. Such an artifact may contribute to the emergence of a common interpretation framework. The purpose here is to provide a basis 
for fruitful discussion and negotiation of new meanings for future projects rather than to reach a congealed group consensus which, as Fiol (1994) indicates, may be considered as artificial.

\subsection{Case study $n^{\circ}$ 3: Cognitive representations in a multi-firms development project}

When people are telling the story of an innovation project, they are talking either of the product itself (how they imagine the future product) or of the process (how activities are or should be undertaken). This case-study was aimed at identifying how representations of the product could influence the unfolding of the process. Representations of a new product are multi-dimensional. Flichy (1995) identified two dimensions in what he defines as the "socio-technical framework" of a project. The first one is the technical, functional side of an engineering activity, the second aspect is related to the social use and the product value for the future users. The designers in fact have to take into account both the technical and the social aspects of product usage. These two dimensions, sometimes more simply referred to as functions (technical aspects) and applications (usage aspects), should in our opinion be completed by a strategy concern that also influences the collective representations of the future new product. This strategy dimension includes internal knowledge such as the strategic objectives of the firm and the evaluation of its competencies to undertake a technological development, and external knowledge such as the perception of environmental constraints and competitive issues.

Cognitive representations on a new product can then be articulated within a two dimensions matrix: product versus firm's strategy and internal versus external knowledge (Tab. 3). We argue that these elements are mutually dependent and that their evolution progressively leads to the design of different intermediate artifacts (specifications documents, user-studies, prototypes) and then to the final product. These artifacts are reification tools which structure the collective negotiation process during the project.

TABLE 3. - Constitutive elements of representations of an innovation project.

\begin{tabular}{|c|c|c|}
\hline & PRODUCT & STRATEGY \\
\hline INTERNAL VISION & $\begin{array}{l}\text { Functional framework: } \\
\text { - Product functions } \\
\text { - Constraints, norms } \\
\text { - Technical choices } \\
\text { => technical vision of the product }\end{array}$ & $\begin{array}{l}\text { Strategic objectives } \\
\text { - Strategic vision and objectives } \\
\text { - Core-competencies (competitive } \\
\text { advantage) evaluation } \\
\text { - Capitalizing on competencies and } \\
\text { technologies for product development }\end{array}$ \\
\hline EXTERNAL VISION & $\begin{array}{l}\text { Usage framework: } \\
\text { - User problem to be solved } \\
\text { - Target markets } \\
\text { - Required features } \\
\text { - Usage conditions } \\
\text { => marketing vision of the product }\end{array}$ & $\begin{array}{l}\text { Environment and competitive analy- } \\
\text { sis } \\
\text { - Industry or sector characteristics } \\
\text { - Strategy of competitors } \\
\text { - Technology of competitors } \\
\text { - Existing alternative solutions to the } \\
\text { customer problem. }\end{array}$ \\
\hline
\end{tabular}


The empirical results of this case-study confirmed that some gaps in representations of these four dimensions could affect the overall unfolding of the project. The project team including members of three different firms worked together for several months without redefining the requirements document according to new knowledge and without sharing the same interpretation of crucial issues such as:

- the target market for the new product: the designer assumed that new housing was the most interesting target, whereas the two partner firms wished to address in priority the rehabilitation market;

- the main functions of the product: for one firm, the product was mainly a plastic plinth to hide water pipes for heating, for the other firm and the designer, the product also had to allow electrical power transmission.

Furthermore, the strategic objectives of both industrial partners were different: for the public enterprise, the main objective was to develop a product to promote gas heating installations in old housing. The industrial partner, however, intended to take advantage of the firm's core competencies (PVC pipes, extrusion technology) to develop a multifunctional product targeting as broad a market as possible. These different strategic orientations had not been clearly understood by the design consultant and remained tacit during the design study. In addition, there was a lack of information and discussion about competitive solutions so that the positioning of the new product remained vague. As a result, the qualitative user-study did not reveal very optimistic sales forecasts which led to the decision to stop this project.

Since the project had already been stopped at the time of our study, we cannot be certain that our findings will generate a learning process. The only assumption we can formulate is that this type of study could provide these firms with a framework for structuring knowledge creation and communication for future projects. It is important to note that, in the case of industrial partnership for product development, the strategic intents should not remain tacit since they may influence design choices and be sources of ambiguity. As project activities unfold, participants should discuss alternatives and negotiate critical choices such as target markets, applications, product functions and required competencies.

\section{Discussion}

We have presented two methods for studying innovation processes, one being related to an information-processing paradigm, the other referring to language and cognitive representations of actors involved in innovation activities. The first perspective mainly focuses on the organizational structure and the processes and provides a more comprehensive vision of the process itself and the interactions between different departments of the firm or with the environment. A concrete result resides for example in the improved understanding of market information processing. Thus, this type of diagnosis can help managers become aware that it is useless to invest massively in market information collecting unless this information is efficiently interpreted, stored and distributed within the organization in order to generate new ideas. Managers can also develop a new understanding of competitive threats and consequently reorganize their competitive scanning system. 
The cognitive approach analyzes the capacity of individuals who are involved in innovation projects to communicate with common interpretation frames (particularly concerning the firm's strategy) and a common language. The emergence of a common reference frame can help manage the innovation processes more efficiently by identifying ambiguous interpretations on key issues and allowing a rapid reorientation of collective action. Lastly, the identification of language distances between individuals contributes to highlight conflicts or simple misunderstandings points on important concepts such as marketing, value, strategy, etc.

Field research experiments adopting these two methods related to different theoretical perspectives allow us to suggest a reflection on a unified method combining both dimensions for studying complex processes. Although underlying theoretical and even epistemological assumptions are generally vigorously opposed, we argue that the search for interaction between the organizational and the cognitive levels presents a double interest: theoretical and managerial.

\subsection{Theoretical implications: the duality between structure and social interactions}

Much current work on innovation considers the inherent tension between the exploitation of existing solutions or organizational routines, and the exploration of new possibilities (March, 1991; Paulré, 1993; Nonaka, 1990). Collective learning processes involved in any innovation project are based both on a form of structure stability, allowing for past experience to be stored in a collective memory, and a capacity to break away from organizational routines by creating new interpretation frames. Organizational structure can be defined as a set of rules and resources that recur in social practices, conferring to the organization a time and space permanence (Giddens, 1994). The organizational structure enables social interactions by allowing for physical encounters (formalized structures such as new products committees), control panels, project management tools, or communication facilities using information technologies. The systems diagnosis is clearly mainly focused on evaluating structure-related elements: decision rules, information resources, coordination mechanisms within the organization. It provides an overview of the coherence between the organizational structure and innovation projects and strategy of the firm.

On the other side, the organization consists of a set of relationships (a structure) that enable immediate knowledge connections within communities of practice. These knowledge connections require an adequate self-description by the organization which forms a common reference frame (Von Krogh et al., 1994). This means that an apparently adequate structure enhancing social interactions is not sufficient if gaps of representations remain. Furthermore, we cannot rely only on shared practices to automatically bring individual representations closer. We observed that some important points such as strategic issues may never be raised and may therefore result in durable misunderstandings. Consequently a cognitive approach attempting to highlight representations can provide favorable conditions for a learning process. This learning process is based on the reification of tacit representations and the creation of a shared repertoire allowing negotiation of new meanings amongst project members. 


\subsection{Managerial implications: The role of language and representations in project management}

Considering structural issues along with cognitive issues could also be a way to enrich traditional modes of innovation management. Project organization can actually be considered as an attempt to compromise between a stable structure allowing control and enough flexibility to generate fruitful interactions and creativity among team members. New collaborative technologies such as groupware systems at present mainly focus on increasing information transmission efficiency rather than facilitating representation sharing. However some tools aimed at a better understanding of actors' representations have been developed and experimented. Some of them allow the design and sharing of individual cognitive maps during an innovation project (Lee et al., 1992; Boland et al., 1994). We are also now working on the feasibility of developing dictionaries of key concepts (e.g. project, project manager, user requirements, market study...) accessible through an intranet system, that could be regularly enriched by the individual project members. Other managerial recommendations could be drawn from the complementarity of an information-processing approach and a cognitive approach. If, for instance, a firm is trying to create a common organizational language, with internal communication measures or training projects, it should design simultaneously appropriate structures such as innovation committees where this language will be used in concrete situations. Furthermore, as organizational language is constantly changing and new knowledge is always being introduced, such processes of reification should be undertaken regularly.

\section{Conclusion}

The research methods presented in this article were designed to provide a detailed understanding of the innovation processes by considering two levels of analysis: the organizational structure and the social interactions. These two methods inspired by different, often opposed, theoretical approaches were experimented in several firms. They proved to be relevant in the firms where they were implemented and contributed to a form of organizational learning. However, focusing on one level of structure or another does bring out results that are different in nature. Organizational structures such as task forces or project teams may engender collective practices in which new meanings emerge. Reciprocally, spontaneous involvement in a collective project may result in a modification of existing structures or routines. Accordingly, our suggestion would be to consider both levels - organizational and cognitive - not as distinct characteristics of organizational knowledge, but rather as a duality. This duality between structure and action is the central argument of Giddens's structuration theory, which is based on the idea that structure is both input to and output of human actions. Within this perspective, it would be of interest to promote a global and longitudinal method for studying innovation processes, that would take into account this duality: a systems diagnosis could provide a general overview of the organizational structure and the information-processing system, while the study of cognitive representations could reveal how people apprehend 
the firm's strategy and their role in an innovation project. In addition, this interaction between an information-processing perspective and a cognitive perspective can provide a better understanding of the learning dynamics involved in innovation processes.

Acknowledgments. The author would like to thank Professors Alain Charles Martinet, Bernard Paulré, as well as two anonymous referees for their insightful comments.

\section{References}

Argyris C., Schön D. (1978) Organizational Learning: a Theory of Action Perspective, Addison-Wesley.

Argyris C., Schön D. (1996) Organizational Learning II, Theory, Method and Practice, Addison-Wesley.

Argyris C. (1995) Savoir pour agir. Surmonter les obstacles à l'apprentissage organizationnel, Interéditions, Paris.

Bateson G. (1980) Vers une écologie de l'esprit, Tome 1, Éditions du Seuil, Paris, trans. of: Steps to an Ecology of Mind, 1972, Chandler Publishing Company, New York.

Baumard P. (1996) Organizations déconcertées. La gestion stratégique de la connaissance, Masson, Paris.

Boland R.J., Tenkasi R.V., Te'eni D. (1994) Designing information technology to support distributed cognition, Organization Science 6, pp. 456- 475.

Brown W., Karagozoglu N. (1989) A systems model of technological innovation, IEEE Transactions on Engineering Management 36, pp. 11-16.

Chanal V. (1995) Le management de l'innovation de produit industriel: mise en ouvre d'une démarche de diagnostic pour améliorer notre compréhension du processus, Thèse de doctorat en sciences de gestion, Université Pierre Mendès France de Grenoble, École Supérieure des Affaires.

Cohen W., Levinthal D. (1990) Absorptive capacity: a new perspective on learning and innovation, Administrative Science Quarterly 35, pp. 128-152.

Cooper R. (1983) A process model for industrial new product management, IEEE Transactions on Engineering Management EM-30, pp. 2-11.

Cossette P., Audet M. (1994) Qu'est-ce-qu'une carte cognitive ?, in Cartes cognitives et organisations, sous la dir. de P. Cossette, Presses de l'Université Laval, Editions Eska, pp. 13-33.

Daft R., Weick K. (1984) Toward a model of organizations as interpretation systems, Academy of Management Review 9, 2, pp. 284-295.

Fiol M. (1994) Consensus, diversity and learning in organizations, Organization Science 5, 3, pp. 403-420.

Flichy P. (1995) L'innovation technique. Récents développements en sciences sociales. Vers une nouvelle théorie de l'innovation, La Découverte, Série Sciences et Sociétés, Paris.

Garel G., Midler C. (1995) Concourance, processus cognitifs et régulation économique. Revue Française de Gestion, juin-juillet-août. pp. 87-101.

Giddens A. (1984) The Constitution of Society, University of California Press.

Girin J. (1990) Problèmes du langage dans les organisations. In: J.F. Chanlat (Eds), L'individu dans l'organisation, les dimensions oubliées, Editions Eska, Laval. 
Glazer (1991) Marketing in a information-intensive environment: strategic implications of knowledge as an asset, Journal of Marketing 55, pp. 1-19.

Grant R. (1996) Toward a knowledge-based theory of the firm, Strategic Management Journal 17 (special issue), pp. 109-122.

Hatchuel A. (1994) Apprentissages collectifs et activités de conception, Revue Française de Gestion, juillet-août.

Hutchins E. (1995) Cognition in the Wild, MIT Press, Cambridge (Mass.).

Lee S., Courtney J.F., O'Keefe R.M. (1992) A system for organizational learning using cognitive maps, Omega, International Journal of Management Science 20, 1, pp. 23-36.

Le Moigne J.L. (1990) La modélisation des systèmes complexes, Paris, Dunod.

March J. (1991) Exploration and exploitation in organizational learning, Organization Science 2, pp. 71-87.

Maturana H.R., Varela F.J. (1994) L'Arbre de la connaissance, Paris, Addison-Wesley.

Ménard C. (1994) La nature de l'innovation organisationnelle. Eléments de réflexion, Revue d'Economie Industrielle, numéro hors-série, pp. 173-192.

Midler C. (1996) L'auto qui n'existait pas. Management des projets et transformation de l'entreprise, Paris, Interéditions.

Nelson R., Winter S. (1982) An Evolutionary Theory of Economic Change, Belknap Press, Cambridge (Mass.).

Newell A., Simon H.A. (1972) Human Problem Solving, Prentice Hall.

Nonaka I. (1990) Redundant, overlapping organization: a japanese approach to managing the innovation process, California Management Review spring, pp. 27-38.

Nonaka I. (1994) A dynamic theory of organizational knowledge creation, Organization Science 5, 1, pp 14-37.

Paulré B. (1993) Apprentissage et systémique. L'analyse du changement technique: entre préformisme et constructivisme, Économies et Sociétés, Série Dynamique technologique et organization 1, 5, pp. 25-61.

Pettigrew A. (1990) Longitudinal field research on change: theory and practice, Organization Science 1, 3, pp. 267-291.

Pettigrew A. (1992) The character and significance of strategy process research, Strategic Management Journal 13, pp. 5-16.

Roos J., Von Krogh G. (1996) Managing Knowledge: Perspectives on Cooperation and Competition, Sage.

Suchman L. (1987) Plans and Situated Action: the Problem of Human-machine Communication, New York, Cambridge University Press.

Tsoukas H. (1996) The firm as a distributed knowledge system: a constructionist approach, Strategic Management Journal 17 (special issue), pp. 11-25.

Van de Ven A. (1986) Central problems in the management of innovation, Management Science 32, 5, pp. 590-607.

Van de Ven A., Huber G. (1990) Longitudinal field research methods for studying processes of organizational change, Organization Science 1, 3, pp. 213-219.

Van de Ven A., Poole M.S. (1990) Methods for studying innovation development in the Minnessota Innovation Research Program, Organization Science 1, 3, pp. 313-335.

Varela F. (1989) Connaître les sciences cognitives, Seuil, Paris. 
Von Hippel E. (1989) New product ideas from lead users, Research Technology Management, may-june, pp. 24-27.

Von Krogh G., Roos J., Slocum K. (1994) An essay on corporate epistemology, Strategic Management Journal 15, pp. 53-71.

Weick K. (1979) The Social Psychology of Organizing, Random House.

Weick K. (1995) Sensemaking in Organizations, Sage Publications.

Wenger E. (1998) Communities of Practice. Learning, Meaning and Identity, Cambridge University Press. 